\title{
Anmeldelser
}

\section{Solen ved Midnat}

\author{
Johnny Kondrup
}

Uffe Jonas: Solen ved Midnat. Grundtvigs Sang til Kosmos. Uden udgivelsessted, men trykt i Litauen. Udgivet af forlaget GrundtvigNU 2015. 735 sider, 469 kr.

Uffe Jonas, der er ph.d. på en afhandling om Søren Kierkegaard (fra 1998) og tidligere har skrevet flere forskningsartikler om Grundtvig, ønsker med denne digre afhandling at vise, hvilken visionær tænker Grundtvig var, hvilke højder og dybder hans forfatterskab rummer. Afhandlingen med den poetiske titel er en hyldest til Grundtvigs "fantastiske sangunivers", som det hedder i bagsideteksten, men også frugten af et toårigt Carlsbergfond-stipendium og har således videnskabelige ambitioner. "Grundtvigs poetiske tænkemåde bliver sat ind i et bredt historisk og internationalt perspektiv", hedder det sammesteds. Og: "Hans tænkning er forankret i en historisk traditionsbevidsthed, der rækker helt ud i de dybeste afkroge af den klassiske europæiske dannelseskultur."

På den baggrund kunne man nære forhåbninger om, at Uffe Jonas' afhandling ville give især den litterære Grundtvigforskning en vitaliserende indsprøjtning. Med sådanne forhåbninger mødte i hvert fald denne anmelder bogen.

Det begynder også lovende. Jonas tager udgangspunkt i den såkaldte danske panteismestrid 1814-15 mellem Grundtvig og H.C. Ørsted - den 
strid, hvori Grundtvig anklagede den romantiske naturfilosofi, først og fremmest repræsenteret af Schelling, for at være panteistisk ("uchristelig, ugudelig og løgnagtig", som det hed i undertitlen på hans skrift Imod den lille Anklager). Det er en vigtig begivenhed, som tidligere er blevet behandlet i forskningen: af C.I. Scharling i dennes disputats Grundtvig og Romantiken (1947), af Erik M. Christensen i et forsøg på at bestemme guldalderens idéhistoriske fundament som "optimistisk dualisme" (1966), af Erland Jessen i Grundtvig-Studier 1971 og senest af Dan Charly Christensen i hans store biografi af Ørsted, Naturens tankeleser, 2009.

Jonas behandler imidlertid striden som en kamp mellem to verdensbilleder: det ptolemæiske eller geocentriske, repræsenteret af Grundtvig, og det kopernikanske eller heliocentriske, repræsenteret af Ørsted. Dette aspekt, som ikke tematiseres i striden selv, bliver for Jonas hovedsagen og kommer til at skygge for eller fortegne dens egentlige proportioner. For kontrastens skyld bliver H.C. Ørsted gjort ansvarlig for den mekanistiske naturvidenskabs verdensbillede, ja nærmest til en tidlig repræsentant for positivismen, skønt han rettere var en modstander af 1700-tallets åndløse empirisme. Ørsted og Schelling stilles på linje med Kant (imod Grundtvig), skønt de begge gjorde op med Kants erkendelsesteoretiske adskillelse af tingen i sig selv og de menneskelige anskuelsesformer. Ørsted og Schelling kaldes "naturfilosofiens materialister" (46) til forskel fra Grundtvig, der betegnes som idealist - skønt både Schelling, Ørsted og den unævnte Steffens var banebrydende repræsentanter for den idealistiske naturfilosofi. Jonas garderer sig delvis ved at lade Grundtvig gennemskue, "at der skjult i den tyske idealisme lå kimen til den videnskabelige materialisme" (28). Men forvirrende er det alligevel, og bedre bliver det ikke, da Jonas vil gøre Grundtvigs opgør med naturfilosofferne til et opgør med en dualistisk tendens i den vestlige filosofi. Sandheden er snarere den modsatte, at teisten og dualisten Grundtvig bekæmpede monisterne Schelling og Ørsted som panteister.

Konsekvenserne af denne misvisning i anslaget er ganske langtrækkende. For at gøre Grundtvig til den originale spiritualistiske og "økologiske tænker” (67), som Uffe Jonas ser i ham, skæres han ud af sin historiske kontekst, der netop var en ny og visionær bevægelse på spiritualistisk eller idealistisk grundlag: universalromantikken. I et ambitiøst program omfattede den såvel naturvidenskab som kunst, historie, filosofi og religion, hvis ytringer alle mentes at repræsentere og føre til indsigt i det ene, ån- 
den. Ørsted lagde som andre universalromantikere vægt på enheden af det gode, det sande og det skønne og beskrev f.eks. naturlovene som Guds tanker. Men Jonas hævder tværtimod, at i Grundtvigs samtid "stod [intet] i visdommens, helliggørelsens og livsopbyggelsens, men alting i videnskabeliggørelsens, materialiseringens og opløsningens tegn” (324).

Denne selvpåførte blindhed giver sig undertiden bizarre udslag. Et eksempel er, da Grundtvig bliver udnævnt til fænomenolog i sit naturforhold og hyldet, fordi han "lægger den konkrete sansning og naturinteraktion til grund for sine iagttagelser" (545). Bortset fra den sproglige iklædning kunne man med betydeligt større ret sige dette om samtidige naturforskere og -filosoffer som Goethe, Steffens og Ørsted. Vel var Grundtvig meget, men fænomenologisk naturiagttager er ikke den betegnelse, der først melder sig, og Uffe Jonas' belæg er heller ikke overbevisende:

For Grundtvig er blomsten at betragte nærmest som en lille rodfæstet engel, et levende paradisisk og intenst kommunikerende væsen, hvis ekstatiske væren antydes i duften, der ligefrem kan opvække erindringen om livet og dets kosmiske oprindelse i særligt følsomme næsebor. (546)

Et andet eksempel er, da de chladniske klangfigurer omtales (således benævnt efter den tyske musikeksperimentator og -teoretiker E.F.F. Chladni, der beskrev dem i 1802). Disse harmoniske mønstre, som lydsvingninger kan frembringe i sand eller heksemel, blev af en begejstret H.C. Ørsted betragtet som bevis for sammenhængen mellem naturvidenskab og kunst, legeme og sjæl. Ørsted forsøgte yderligere at indtolke fænomenet i en dynamisk teori om elektricitet, der overskred Chladnis egen mekaniske forklaring af det. Han publicerede i 1810 en afhandling om klangfigurerne, som førte til hans optagelse i Videnskabernes Selskab, og beskrev tonernes vellyd som "Naturens dybe uendelige, ufattelige Fornuft". Men Uffe Jonas nævner end ikke Ørsted i denne forbindelse. I stedet introducerer han "grundlæggeren af kymatikken, den schweiziske fysiker, kunstner og naturvidenskabsmand, Hans Jenny (1904-72)" som den, der byggede videre på Chladnis iagttagelser. Og han fortsætter:

Kymatik er læren om lyd, vibrationer og bølgevirkninger og deres indvirkning på formdannelsen i alt fra molekyler til galakser. Igennem 
sine omfattende studier af den akustiske fænomenologi nåede Jenny frem til den konklusion, at lyd er, om ikke selve den skabende kraft i universet, så i det mindste det oprindelige medium, som denne skaberkraft ytrer, forplanter og manifesterer sig igennem (276).

Jonas tilføjer: "Jennys konklusion bekræftes af alle verdens oprindelige skabelses-spirituelle traditioner" (277), og derefter bringes Albert Einstein ind i billedet, dog på anden hånd via William Hermanns' samtalebog Einstein and the Poet - In Search of the Cosmic Man (1983).

Einstein spiller en ikke uvigtig rolle for Jonas, hvis bestræbelse er at gøre ham og Grundtvig 'samtidige'. Jonas glæder sig f.eks. over et citat af Einstein, der kan udlægges sådan, at naturvidenskaben er en rekonstruktion af den højeste intelligens, som ytrer sig gennem naturlovene (327). Ligeså fejrer Jonas, at både Einstein og Grundtvig anså naturvidenskab, religion og kunst for konvergente (329 f.). Ørsted ville også her være en mere nærliggende samtidig.

Dette er så den anden konsekvens af Uffe Jonas' indledende manøvre: Samtidig med at Grundtvig skæres ud af sin historiske sammenhæng, indsættes han i en ny kontekst, der består af alverdens religiøse, til dels okkulte traditioner, moderne spiritualister af den art, som ofte sammenfattes under paraplyen "new age", og avancerede naturforskere fra det 20. århundrede - de sidste dog gerne i populære aftapninger på engelsk. (En anden kilde til Einsteins univers hedder f.eks. The Expanded Quotable Einstein, en tredje Einstein and Buddha - the Parallel Sayings).

Dette brogede selskab rystes sammen med forsikringer som de følgende, parafraseret efter kapitel 5, der hedder "Big bang, begyndelser, æoner og epoker": Den moderne naturvidenskab er nu kommet så tæt på universets oprindelse, at den begynder at konvergere med de gamle visdomstraditioners beretninger om verdens skabelse (156). I virkeligheden siger den moderne, post-einsteinske fysik det samme som skabelsesberetningerne: at materien er 'underkølet ånd', og at bevidstheden altså er det primære (170). Undervejs får Grundtvig et ord med på vejen, som her efter kapitel 6, "Ordet og Røsten”: Ved at anerkende 'det trefoldige Maria-billede' eller 'den sophianske treenighed' - under alle omstændigheder et feminint modsvar til treenigheden - foregriber Grundtvig den nye sophiansk-marianske teologi, som først nu og så småt er under formulering (190). Dette kapitel og det følgende, der tilsammen eftersporer Grundtvigs Maria-fromhed, er i 
øvrigt nok de mest solide i bogen. Men ellers er det ikke meget, Grundtvig fylder i selskabet. Over lange stræk er Uffe Jonas' bog et panorama over tankegodset i moderne spiritualisme og esoterik, afbrudt af korte forsikringer om, at Grundtvig mente præcis eller nogenlunde det samme.

$\mathrm{Nu}$ er det vel i sig selv ikke mærkeligt, at Grundtvigs tankegang, forankret som den var i det romantisk-idealistiske verdensbillede, der blev bortdømt fra den herskende offentlighed af naturalisme, darwinisme og positivisme i slutningen af 1800-tallet, udviser lighedstræk med moderne spiritualisme og esoterik, som netop repræsenterer en subkulturel rest eller videreførelse af det samme verdensbillede. Mere bemærkelsesværdigt er det, at Uffe Jonas gør så lidt ud af Grundtvigs forfatterskab. For sagen er jo, at der her, især i den lyriske del, findes mere poetisk saft og kraft end i de blege new age-filosoffer og naturvidenskabsfolk, som Uffe Jonas bringer ham i selskab med.

Som man vil forstå, er det en særlig pointe for Uffe Jonas, at Grundtvigs verdensbillede var geocentrisk, og på et tidspunkt understreger han, "at den poetiske overbevisningskraft i Grundtvigs salmeunivers med dets himle, lysvæld, engleskarer og underverdener først for alvor bliver indlysende, når man betragter det på baggrund af denne [...] tænkemåde” (571). Det forekommer meget sandsynligt, ligesom det giver god mening at hævde, at dette verdensbillede stadig er en gangbar måde at beskrive den menneskelige livsverden på (til forskel fra den videnskabelige 'systemverden’). Vi lever til daglig på en jord, hvorover solen står op i øst og går ned i vest, når den har gjort sin gerning. Hvis Uffe Jonas havde ladet det forblive herved og så påvist, hvordan det geocentriske perspektiv faktisk kan aflokke Grundtvigs digtning mere eller mindre glemte betydninger, kunne han have skrevet en bog af blivende betydning. Men i stedet kaster han sig ud i vidtløftige argumentationer for, at den moderne naturvidenskab giver geocentrikerne ret, og at det heliocentriske verdensbillede er blevet overhalet indenom, blandt andet fordi universet slet ikke har noget centrum. Argumenterne fører ikke ind i Grundtvigs digtning, men ud i galakserne.

At dømme efter citater og henvisninger er hovedkilderne til Uffe Jonas' forståelse af Grundtvigs forfatterskab følgende: afhandlingen "Om Mennesket i Verden” fra Danne-Virke 1817; Udsigt over Verdens-Krøniken fra samme år; en anmeldelse af A. Aschlunds bog Om Verden-Bygningen i Maanedsskrift for Christendom og Historie 1831 og artiklen "Den Coperni- 
kanske Astronomi som den fjerde Troes-Artikel” i Nordisk Kirke-Tidende 1837. Dertil kommer to utrykte artikler: "Om Christendom og Astronomi” 1837 (Grundtvig-arkivet, fasc. 123.1), og "Historie og Naturalisme eller Tids og Rums Oplysning” 1865 (Grundtvig-arkivet, fasc. 139.1). De to sidste bringes som bilag på tilsammen 14 sider. Resten af de ca. 40.000 sider, som Grundtvig lod trykke, og de ca. 90.000 manuskriptsider, som findes bevaret, får kun glimtvis adgang til fremstillingen. Af det lyriske forfatterskab finder man en strofe hist og en strofe her, men ofte på den måde, at citaterne afslutter et kapitel og står som en slags bevis for, at Grundtvig mente det samme, som netop er blevet afhandlet. De tilhørende fortolkninger er generelt spinkle og omtrentlige.

Bogen vidner heller ikke om nogen stor fortrolighed med det grundtvigske tankegods, som normalt optager forskningen. Et begreb som "det levende ord" optræder ganske vist adskillige gange og synes at have i hvert fald fem betydninger: Hyppigst betyder det Guds skaberord, næsthyppigst Jesus Kristus; undertiden betyder det blot det talte ord i modsætning til det skrevne; en sjælden gang betyder det nærmest Helligånden, der skal tage bolig i menneskenes hjerter for at forvandle det skrevne til liv; og en enkelt gang betegner det den indre stemme, hvormed solen eller Gud [!] kalder mennesket opad (hvilket i parentes bemærket skal være forklaringen på fænomenet levitation). Men på intet tidspunkt betegner det levende ord udkommet af Grundtvigs 'mageløse opdagelse' i 1825, dvs. hans forståelse af trosbekendelsen, Fadervor og nadverindstiftelsesordene som grundlaget for kristendommen, fordi de er udgået af Kristi egen mund og altså ligger forud for Bibelen.

Selv om Grundtvig er emnet for Uffe Jonas' bog, synes han og hans forfatterskab altså ikke at udgøre dens egentlige perspektivpunkt. Det ligger snarere hos den hermetiske magiker og kristne mystiker Valentin Tomberg (1900-1973). Han var af russisk oprindelse og i sin ungdom elev af antroposofiens grundlægger Rudolf Steiner, men efter i 1940 at være blevet ekskluderet af det antroposofiske selskab på grund af sin okkulte forskning konverterede han til katolicismen. Hans hovedværk, som blev til efter 1960, er Méditations sur les 22 arcanes majeurs du Tarot. Det blev publiceret anonymt i 1984 med forord af en kardinal og oversat til engelsk som Meditations on the Tarot i 1985. Dette værk, som i dag nyder høj anseelse blandt yngre intellektuelle spiritualister, leverer de mest sammenbindende og autoritative citater i Uffe Jonas' bog. I et kort appendiks skriver 
forfatteren rent ud: "Meditations on the Tarot har for mig vist sig at være en ganske enestående præcis nøgle til forståelsen af det kristne hermetiske verdensbillede, der ligger til grund for Grundtvigs forfatterskab” (718). Det betyder ikke, at Tomberg har læst noget hverken af eller om Grundtvig, men blot, at Jonas bruger Tomberg som en slags facitliste til forfatterskabet - foruden til meget andet, herunder forståelsen af universets tilblivelse, menneskehedens bevidsthedsudvikling og kødets opstandelse. I de tilfælde, hvor det drejer sig om Grundtvig, forekommer facitlisten nu ikke at være så enestående præcis som hævdet, hvad der klarest kommer til udtryk i en formulering som denne:

Overvindelsen af døden betyder $\mathrm{i}$ virkeligheden intet mindre end overvindelsen af selve modsætningen mellem ånd og krop, liv og død. Sådan tænkte Grundtvig, og sådan tænker også en anden af den kristelige tænknings store læremestre, Valentin Tomberg. Hvad Grundtvig kalder for livets definitive sejr over døden, det opfatter Tomberg snarere som en syntese af liv og død [ - hvorefter følger et langt citat af Tomberg] (421).

Det skal ikke være unævnt, at adskilligt i Uffe Jonas' bog virker sympatisk, i hvert fald på denne anmelder. Det gælder sansen for livet som et dagligt fornyet under, ligesom det gælder nænsomheden over for kloden og dens skrøbelige økosystem. Endvidere overbevisningen om, at ånd er en grundlæggende tilværelsesmagt, og modet til at udfordre vedtagne forestillinger, også i videnskaben. Men i denne sammenhæng er det min opgave at bedømme bogen især som bidrag til Grundtvigforskningen, og på det felt er den en skuffelse.

Der er meget i Uffe Jonas' bog, som jeg ikke kan bedømme med sagkundskab. Det gælder først og fremmest redegørelserne for den avancerede naturvidenskab og til dels for de esoteriske traditioner. At jeg alligevel forholder mig tøvende også til disse dele, har to årsager: For det første, at de ting, som jeg faktisk kan bedømme, især de litteratur- og idéhistoriske udredninger, ikke er hverken præcise eller overbevisende. For det andet, at kilderne til en stor del af det øvrige stof er af en art, som jeg ikke ville bygge en alvorlig anskuelse af verden på. Som sagt er de store naturforskere oftest gengivet i populære andenhåndsaftapninger, gerne skrevet af amerikanske new age-forfattere. Det samme gælder væsentlige dele af den 
religiøse og filosofiske tradition - Platon citeres f.eks. efter Jamie James: The Music of the Spheres - Music, Science and the Natural Order of the Universe (1995), hvilket fører til, at et citat fra 7. bog af Staten omtales som hentet i 8. bog af Republikken (529). Også de moderne esoterikeres indsigter er ofte hentet fra kompilationer med titler som f.eks. The Essential Seyyed Hussein Nasr. Jævnligt fungerer opslag fra engelsk Wikipedia (uden konsultationsdato) som dokumentation for vidtrækkende påstande, ligesom der henvises til foredrag og andre videoer på YouTube.

Når det kommer til spørgsmålet om akribi, må anmelderen løbe risikoen for at blive regnet blandt de tonedøve atomister, som Uffe Jonas foragter. Alle fremmedsproglige citater er oversat til dansk uden videre - og uden at originalen bringes til sammenligning. Ofte har originalen dog heller ikke været Uffe Jonas' forlæg, fordi han har benyttet en engelsk version - tysk sekundærlitteratur forekommer næsten ikke og fransk slet ikke, så både Luther, Mester Eckehart og Hildegard af Bingen er læst på engelsk. I de stikprøver, jeg har foretaget i citater fra danske kilder, er gengivelsen ofte fejlbehæftet, dog kun sjældent med direkte meningsforstyrrende virkning. Såvel notehenvisningerne som bogens litteraturliste er generelt upræcise, inkonsekvente og utilstrækkelige. Men der findes et register over både personer og emner. 